\title{
Advokat dan Hukum Ekonomi di Indonesia
}

\author{
Abdul Haris Naim \\ Institut Agama Islam Negeri Kudus \\ harisnaim869@gmail.com
}

\begin{abstract}
The role of law graduates in Indonesia is very important in overcoming problems that exist in society when working as an advocate. But sometimes the profession sometimes gets a slanted view in the middle of society. This is due to the lack of literacy from the general public. Important advocates need to be considered because in addition to providing legal advice by defending the rights of suspects in criminal and civil cases. In criminal cases, the client's interests are subjectively separated from the law, even though the suspect realizes that he made a mistake. Almost never heard of a voluntary criminal willing to be convicted. So the role of advocates in upholding economic law in Indonesia is really needed. Without the role of an advocate, law enforcement, especially those relating to economic law will not be enforced.
\end{abstract}

Keywords: Advocates, Laws, Economic Law in Indonesia

\begin{abstract}
Abstrak
Peran Sarjana hukum di Indonesia sangatlah penting dalam mengatasai permasalahan yang ada di masyarakat ketika berprofesi sebagai Advokat. Namun terkadang profesi itu terkadang mendapatkan pandangan miring di tengah masyarakat. Hal ini disebabkan karena adanya literasi yang kurang dari masyarakat pada umumnya. Advokat penting perlu diperhatikan karena selain memberikan nasehat hukum dengan membela hak-hak tersangka dalam perkara pidana dan perdata. Dalam perkara pidana, kepentingan klien secara subyektif adalah lepas dari jerat hukum, kendati tersangka menyadari telah melakukan kesalahan itu. Hampir tak pernah terdengar ada penjahat yang sukarela bersedia dipidana. Maka peran advokat dalam penegakan hukum ekonomi di Indonesia memang sangat dibutuhkan. Tanpa adanya peran advokat, maka penegakan hukum, khususnya yang berkaitan dengan hukum ekonomi tidak akan dapat ditegakkan.
\end{abstract}

Kata kunci: Advokat, Hukum, Hukum Ekonomi di Indonesia

\section{PENDAHULUAN}

Menurut Harold M Titus (1974), maju mundurnya peradaban ada di tangan sarjana hukum. Namun mengapa profesi yang satu ini acapkali mendapatkan pandangan "miring" di tengah masyarakat. Barangkali, salah satu penyebabnya adalah sifat eksklusivisme profesi pengacara atau advokat ini. Bagaimanapun sebuah profesi yang khusus hanya bisa dipahami oleh mereka yang sama-sama menekuni profesi ini. 
Masyarakat umum kemungkinan kurang paham bagaimana kesulitan yang dihadapi pengacara dalam membangun alibi untuk membela kliennya. Karena hukum menerapkan standar tertentu, maka tidak setiap fakta dalam suatu kasus dapat dijadikan sebagai fakta hukum. Data dan fakta harus dikemas, sehingga dapat utuh dan integral secara hukum. Sedikit saja terjadi kontradiksi atau tak saling menguatkan, seluruh bangunan alibi akan runtuh. Itu berarti malapetaka bagi klien dan tanggung jawab professional (professional liability) pengacara akan dipertanyakan. Pembelaan advokat atas kliennya lebih merupakan law battle dari pada untuk mencari kebenaran, dan bukan terletak di pundak advokat untuk mencari substansi kebenaran dalam suatu perkara, ini kewajiban hakim. Karena itu, tidak mengherankan apabila sudut pandang pengacara atas kebenaran dalam suatu perkara yang ditanganinya cenderung subyektif. Semua serba ditakar dari sisi kepentingan klien. (Abdurrahman, 1986 : 71)

Pekerjaan advokat selain memberikan nasehat kepada hukum adalah membela hak-hak tersangka atau terdakwa dalam perkara pidana, dan memperjuangkan hak-hak klien dalam suatu musyawarah atau membela hak tergugat/ penggugat dalam perkara perdata. Batas inilah yang disebut pekerjaan membela kepentingan klien. Namun bagi sebagian masyarakat, apa yang dilakukan advokat senantiasa tampak sama, yakni membela kepentingan klien dalam pengertian yang subyektif. Apabila advokat mengatakan "demi hukum" kerap kali ditatap dengan penuh tanda tanya dari segi mana hal itu diucapkan. Bahasa awam yang sering terlontar adalah "jelas-jelas orang sudah bersalah masih juga dibela."

Dalam perkara pidana, kepentingan klien secara subyektif adalah lepas dari jerat hukum, kendati tersangka menyadari telah melakukan kesalahan itu. Hampir tak pernah terdengar ada penjahat yang sukarela bersedia dipidana. Di sisi lain, manusia memiliki kecenderungan menang sendiri. Apabila kepentingan klien yang subyektif itu dituruti advokat, doktrinnya adalah harus menang. Apabila klien tegas menyatakan, "harus menang berapapun ongkosnya."

Jika doktrin harus menang ini diikuti, tak tertutup kemungkinan advokat akan melakukan hal-hal yang secara "moral" tercela. Tindakan tersebut dapat merugikan tidak saja orang perorang, tetapi juga dapat mengacaukan penegakan hukum. Karena lawyer termasuk ahli hukum, maka upaya buruk itu biasanya dikemas dan disamarkan sehingga secara hukum sah. Mereka menyelinap melalui celah hukum yang dapat diputarbalikan. Di sini, hukum di tangan advokat menjadi alat atau instrumen untuk mewujudkan kepentingan, termasuk untuk membeli suatu ketidakbenaran. 
Todung Mulya Lubis mengatakan, ada demoralisasi dalam profesi advokat di Indonesia. Sedangkan Adnan Buyung Nasution tahun 1981 menulis, sudah menjadi rahasia umum bahwa di dalam proses pengadilan pun ada tawar menawar mengenai berat ringannya hukuman yang akan dijatuhkan dalam perkara pidana atau tentang siapa yang harus dimenangkan atau dikalahkan dalam perkara perdata.

\section{PEMBAHASAN}

\section{Peranan Hukum Dalam Pembangunan Ekonomi}

Hukum dan ekonomi adalah merupakan dua sub sistem dari suatu sistem kemasyarakatan yang saling berinteraksi antara satu dengan yang lain. Disatu pihak hukum dapat dilihat sebagai hasil dari berbagai kekuatan sosial dan ekonomi yang terdapat dalam proses kemasyarakatan, sehingga hukum itu sangat tergantung sekali pada faktor-faktor yang cukup dominan dalam kehidupan masyarakat terutama faktor-faktor ekonomi. Dengan demikian hukum berada dibelakang dan mengikuti perkembangan ekonomi. Hal ini sesuai dengan anggapan klasik mengenai hukum yang berasal dari orang-orang Belanda dahulu yang mengatakan bahwa "het recht hink achterde feiten aan" (hukum itu ada di belakang dan mengikuti kejadian-kejadian). (Suhrawardi, 1994: 47)

Dalam suasana yang demikian, maka hukum hanya berfungsi sebagai pelayan yang baik dari pada perkembangan ekonomi. Hal ini sesuai dengan pendapat yang menyatakan bahwa hukum mempunyai fungsi pengabdian (dienende functie), apabila suatu proses berubah, maka hukum harus diusahakan untuk dapat menampung perkembangan yang baru itu. Hal yang demikian mengandung banyak konsekuensi dan satu diantaranya yang dikemukakan oleh menteri kehakiman Ali Said. Secara tepat sekali sebagai berikut: "salah satu konsekuensinya ialah bahwa keseluruhan hukum dan sistemnya harus mengikuti perubahan dan menyesuaikan diri dengan perubahan itu sendiri". Bilamana hal ini tidak terjadi, maka akan timbul suasana yang pincang, dimana pada satu pihak masyarakat sudah berkembang maju, pada pihak yang lain hukum yang berfungsi pokok mengatur tata kehidupan masyarakat menjadi lumpuh karena kondisinya telah usang. Dalam suasana yang demikian terwujudlah apa yang acapkali disindirkan orang ke alamat ahli hukum, bahwa hukum berjalan tertatih-tatih di belakang perkembangan masyarakat yang tidak mampu dikendalikan lagi. Akan menjadi kenyataan bahwa himpunan hukum hanyalah huruf-huruf mati yang tiada arti.

Dalam sebagian besar masyarakat demokratis modern, peran ahli hukum sangat penting, bahkan beberapa Negara seperti Amerika Serikat sangat menonjol. Penyebabnya sebagian besar karena konstitusi dan tertib hukum yang demokratis, apapun perbedaan-perbedaan yang ada 
diantara berbagai bentuk demokrasi didasarkan kepada keseimbangan antara fungsi dan kekuatan yang sangat pelik. Hal ini menjadikan pentingnya peranan ahli hukum sebagai orang terlatih dalam menjaga keseimbangan di atas. Fungsi Negara tetap terbatas pada bidang pertahanan, masalah luar negeri, dan kegiatan administrative serta kepolisian, sedangkan arus utama ekonomi dan sosial mengalir melalui saluran-saluran swasta. (Achmad Ali, 2002: 48)

Karena itu pendidikan dan fungsi utama ahli hukum menyangkut bidang hukum perdata, baik sebagai pembela atau penasehat, sebagai hakim yang mengadili pihak-pihak swasta, dan sebagai sarjana hukum yang menganalisa tertib dan konsep hukum dari masyarakat yang termasuk dalam tipe ini.

\section{Peran Advokat Dalam Penegakan Hukum}

Cita-cita demokrasi dan penegakan hukum dapat diwujudkan jika ada Rule of Law. Masalah di atas akan menjadi sulit untuk dipecahkan manakala ternyata "administration of justice" masih belum terpadu, sehingga kedudukan penegak hukum di dalam sistem hukum belum terjamin, begitu juga Catur Wangsa penegak hukum yakni, hakim, jaksa, kepolisian dan advokat adalah "patah". Artinya ketiga kaki telah mempunyai Undang-undang (UU) kecuali avokat, namun demikian, seorang advokat dalam memperjuangkan hak-hak kliennya tidak harus meminta belaskasihan dari elemen Catur Wangsa yang lainnya. Seorang Advokat dalam menjalankan tugasnya diperlukan adanya integritas, karakteristik yang kuat dan tentunya kualitas intelektual yang tinggi. (Ropaun, 2001: 27)

Dalam mengatur hubungan antara profesi advokat dengan kliennya serta masyarakat itulah diperlukan wadah profesi advokat seperti IKADIN 'dan lembaga pengawasan kode etik yang setiap saat seorang advokat dapat disidangkan oleh Dewan Kehormatan dalam menguji pelaksanaan tugas-tugas profesinya. Etika profesi memang benar-benar merupakan hakekat "sine qua non" profesi dan profesionalisme.

Penegakan hukum adalah pekerjaan advokat dan itu merupakan misi profesinya. Ada satu pandangan yang menekankan bahwa penegakan hukum selalu ditekankan pada aspek ketertiban. Hal ini dikarenakan hukum selalu diidentikan dengan penegakan perundang-undangan. Asumsi itu sangat keliru sekali.

Mengapa secara teoritis, memang perundang-undang termasuk salah satu unsur dari sistem hukum tidak hanya terdiri dari perundang-undang maka salah satu akibatnya dapat dirasakan adalah kalau ada bidang kehidupan yang belum diatur dalam perundang-undangan itu, maka dikatakan hukum tertinggal oleh perkembangan dari kebutuhan hukum masyarakat. Akibat lebih jauhnya adalah, kepastian hukum selalu 
diidentikan dengan kepastian undang- undang, maka dalam proses penegakan hukum dilakukan dengan tanpa memperhatikan perkembangan masyarakat yang ada sebagai realitas hukum yang berlaku.

Penegakan hukum pada prinsipnya harus dapat memberikan manfaat atau berdaya guna bagi masyarakat, disamping tercapainya keadilan.

\section{Advokat dan Ruang lingkup Pekerjaannya}

Istilah advokat dan pengacara sebagaimana profesi hukum dalam sejarahnya telah dikenal dengan istilah advocat dan procureur di negara Belanda. barrister and solicitor di Inggris, advocate di Singapura, dan lawyer di Amerika yang sekarang menjadi istilah lazim digunakan secara internasional.

Semua istilah profesi proceur atau pengacara atau solicitor hanya digunakan untuk mereka yang menjalankan khusus hukum acara di pengadilan, sedangkan pekerjaan diluar acara di pengadilan dilakukan oleh advokat/advocate, atau barrister.

Dalam perkembangannya, semua istilah itu, akhirnya hanya memakai istilah advokat/advocaat/advocate atau lawyer yang lazim digunakan hampir di semua negara. (Soerjono, 1999: 31)

Profesi advokat tidak hanya terletak dalam bidang litigasi, akan tetapi mencakup pekerjaan-pekerjaanlain diluar pengadilan yang disebut sebagai pekerjaan non-litigasi, yang meliputi pekerjaan:

1. Memberi pelayanan hukum;

2. Memberi nasehat hokum sebagai penasehat;

3. Memberi konsultasi hukum sebagai konsultan;

4. Memberikan pendapat hukum;

5. Mempersiapkan menyusun kontrak-kontrak;

6. Memberikan informasi-informasi hukum;

7. Membela dan melindungi hak-hak asasi manusia;

8. Memberikan bantuan hukum dengan cuma-cuma (pro hono) kepada rakyat yang lemah dan tidak mampu.

\section{Advokat yang Independen}

Selain karakteristik dan kualitas advokat, diperlukan oleh masyarakat juga integritas seorang advokat diperlukan dalam menjalankan tugasnya. Termasuk di dalamnya pengawasan terhadap dirinya (disciplinary supervision) khususnya tentang perilaku dan hubungannya dengan kliennya karena tanpa adanya pengawasan asosiasi advokat maka di dalam tugasnya dapat terjadi perbuatan atau sikap yang menyimpang dari pada hakekat dari profesi advokat yang notabene sangat diperlukan masyarakat. 
Pengawasan terhadap profesi advokat ini dan segala tingkah laku dan sikapnya tidak cukup dilakukan oleh birokrasi, tetapi sebaiknya diselenggarakan oleh organisasi profesi yang menaungi dan mengawasi prilaku dan sikap advokat. Untuk itu, diperlukan suatu perangkat peraturan atau etika profesi untuk mengatur prilaku dan sikap yang korektif dari seorang advokat sebagaimana halnya juga etika profesi mengatur hubungan antara advokat dengan kliennya, hubungannya dengan rekannya, hubungannya dengan pengadilan, martabat advokat, imunitas advokat, bagaimana seorang advokat harus berpraktek, honor advokat, bagaimana menyelesaikan pelanggaran kode etik dan kualifikasi serta syarat untuk menjadi advokat.

Untuk memenuhi kebutuhan masyarakat yang kompleks dan berubah-ubah dari waktu ke waktu, jelas seorang advokat harus terus mengikuti perkembangan. Karena itu terlibat dalam suatu proses belajar yang tiada hentinya (continuous legal education) dan kewajiban belajar adalah merupakan vonis seumur hidup bagi seorang advokat.

Dalam menjalankan profesinya seorang advokat harus independen. Dia harus bebas dari segala rasa takut, ancaman, dan interversi dari semua pihak dalam membela, memberi nasehat hukum dan mewakili kepentingan kliennya. Dalam memberi pendapat hukum dia harus bebas dari segala bentuk tekanan dan kadang-kadang sebagaimana telah diuraikan di atas harus bebas berbicara di muka umum dan di dalam pengadilan (tribunal) untuk kepentingan klien dan masyarakat. Sebenarnya, ia pun harus turut serta dalam proses reformasi hukum (law reform). (Suhrawardi, 1994: 33)

Di dalam melaksanakan profesi advokat terdapat kaidah-kaidah pokok berupa etika profesi yaitu sebagai berikut:

Pertama, profesi harus dipandang (dan dihayati) sebagai suatu pelayanan, karena itu, maka sifat tanpa pamrih (disintrestednes) menjadi ciri khas dalam mengembangkan profesi. Yang dimaksud dengan "tanpa pamrih" disini adalah bahwa pertimbangan yang menentukan dalam pengambilan keputusan adalah kepentingan pasien atau klien dan kepentingan umum, dan bukan kepentingan sendiri (pengembangan profesi) jika sifat tanpa pamrih itu diabaikan, maka pengembangan profesi akan mengarah pada pemanfaatan (yang dapat menjurus kepada penyalahgunaan) sesama manusia yang sedang mengalami kesulitan atau kesusahan.

Kedua, Pelayanan professional dalam mendahulukan kepentingan pasien atau klien mengacu kepada kepentingan atau nilai-nilai luhur sebagai norma kritik yang memotivasi sikap dan tindakan.

Ketiga, pengemban profesi harus selalu berorientasi pada masyarakat sebagai keseluruhan. 
Keempat, agar persaingan dalam pelayanan berlangsung secara sehat sehingga dapat menjamin mutu dan peningkatan mutu pengembangan profesi, maka pengembangan profesi harus bersemangat solidaritas antar sesama rekan seprofesi. (Soerjono, 1999: 59)

Selain itu dalam pelaksanaan tugas profesi hukum, selain bersifat kepercayaan yang berupa hablu min-annas (hubungan horizontal) juga harus disadarkan kepada hablu min Allah (hubungan vertikal), yang mana hablu min Allah itu terwujud dengan cinta kasih. Perwujudan cinta kasih kepada-Nya itu direlisasikan dengan cinta kasih antar sesama manusia, dengan menghayati cinta kasih sebagai dasar pelaksanaan profesi, maka otomatis akan melahirkan motivasi untuk mewujudkan etika profesi hukum sebagai realisasi sikap hidup dalam mengembangkan tugas (yang pada hakikatnya merupakan amanah) profesi hukum. Dengan itu pengembang profesi hukum memperoleh landasan keagaman, maka ia (pengembang profesi) akan melihat profesinya sebagai tugas kemasyarakatan dan sekaligus sebagai sarana mewujudkan kecintaan kepada Allah SWT dengan tindakan nyata.

Menyangkut etika profesi hukum ini diungkapan bahwa etika profesi adalah sikap etis sebagai bagian integral dari sikap hidup dalam menjalani kehidupan sebagai pengemban profesi. Hanya pengemban profesi yang bersangkutan sendiri yang dapat atau yang paling mengetahui tentang apakah perilakunya dalam mengemban profesi memenuhi tuntutan etika profesinya atau tidak.

Karena tidak memiliki kompetensi teknikal, maka awam tidak dapat memiliki hal itu. Disamping itu, pengemban profesi sering dihadapkan pada situasi yang menimbulkan masalah pelik untuk menentukan perilaku apa yang memenuhi tuntutan etika profesi. Sedangkan perilaku dalam mengemban profesi dapat membawa akibat (negatif) yang jauh terhadap klien atau pasien. Kenyataan yang dikemukakan tadi menunjukan bahwa kalangan pengemban profesi itu sendiri membutuhkan adanya pedoman obyektif yang kongkret bagi perilaku profesinya. Karena itu dari dalam lingkungan para pengemban profesi itu sendiri dimunculkan seperangkat kaidah perilaku sebagai pedoman yang harus dipatuti dalam mengemban profesi.

Perangkat kaidah itulah yang disebut dengan kode etik profesi (bisa disingkat kode etik), yang dapat tertulis maupun tidak tertulis yang diterapkan secara formal oleh organisasi profesi yang bersangkutan, dan di lain pihak untuk melindungi pasien atau klien (warga mayarakat) dari penyalahgunaan keahlian dan atau otoritas professional. 


\section{Profesional Avokat dalam Melaksanakan Tugas}

Sebenarnya para sarjana belum ada kata sepakat tentang apa sebenarnya yang menjadi definisi profesi, sebab tidak ada suatu standar (yang telah disepakati) pekerjaan/tugas yang bagaimanakah yang dikatakan dengan profesi tersebut. "Suatu profesi dapat didefinisikan secara singkat sebagai jabatan seseorang kalau profesi tersebut tidak bersifat komersial, mekanis, pertanian dan sebagainya. Secara tradisional ada empat profesi; kedokteran, hukum, pendidikan dan kependetaan. (Ahmad, 2002: 211)

Profesionalisme biasanya dipahami sebagai suatu kualitas, yang wajib dipunyai setiap eksekutif yang baik. Didalamnya terkandung beberapa ciri;

Pertama, punya keterampilan tinggi dalam suatu bidang, serta kemahiran dalam mempergunakan peralatan tertentu yang diperlukan dalam pelaksanakan tugas yang bersangkutan dengan bidang tadi.

Kedua, punya ilmu dan pengalaman serta kecerdasan dalam menganalisa suatu masalah, dan peka di dalam membaca situasi, cepat dan tepat serta cermat dalam mengambil keputusan terbaik atas dasar kepekaan.

Ketiga, punya sikap berorientsi ke hari depan, sehingga punya kemampuan mengantisipasi perkembangan lingkungan yang terbentang di hadapannya.

Keempat, punya sikap mandiri berdasarkan keyakinan akan kemampuan pribadi ('izzat al-nafs atau self-confidensce), serta terbuka menyimak dan menghargai pendapat orang lain, namun cermat dalam memilih yang terbaik bagi diri dan perkembangan pribadinya.

Dalam Alquran manusia dengan karakteristik, dan kualitas seperti itu dinyatakan sebagai berikut: Gembirakanlah para hamba-hamba-Ku, yang suka menyimak pendapat orang dan (pandai) mengikuti yang terbaik dari padanya, merekalah yang mendapat hidayah Allah dan merekalah ulil al-bab (Q.S. 39:17:18).

Manusia berkualitas seperti itulah yang dimaksudkan Alquran dengan Ulil al-bab bukanlah manusia yang cepat puas dan berwatak nimo. Mereka yakin akan tugas dasar manusia, sebagai makhluk yang memakmurkan kehidupan manusia,".. Dialah (Allah) yang telah menciptakan kamu memakmurkannya..' (Q.S. 11:61). Manusia harus mengembangkan watak pribadinya, juga kemampuan pribadinya, mempunyai watak yang terbuka, suka mempelajari hal-hal baru dan sering mendengar setiap masukan darimanapun datangnya, namun demikian harus pula pandai menyaring masukan nama yang bermanfaat bagi kemajuan individunya.

Selain itu manusia juga harus meyakini akan sifat-sifat sunnatullah yang mengatur alam dan kehidupan di dunia yang pasti, tetap dan obyektif, sehingga mereka tertempa dan mempunyai watak yang 
senantiasa optimis dalam menghadapi masa depan. Pengalaman yang akrab dengan alam telah melahirkan suatu keyakinan yang sedemikian, akan membuat manusia menjadi professional yang sejati, karena sikap ini melahirkan kemampuan berhubungan dengan manusia secara manusiawi (habl min-annas), sebagai suatu syarat mutlak yang harus dipunyai oleh seseorang yang professional.

Bahwa para Profesional Hukum seharusnya bekerja sesuai kode etik bila melanggar mampu bertanggung jawab dan menerima hukuman dari dewan kehormatan, Nilai moralitas didasari perbuatan luhur bangsa. Frans Magnis Suseno mengemukakan empat (4) kriteria nilai moral yang kuat yang mendasari kepribadian professional hukum, adalah;

Pertama, Kejujuran adalah dasar utama. Tanpa kejujuran, maka professional hukum mengingkari misi profesinya, sehingga menjadi munafik, licik, penuh tipu diri dimana sikap jujur yaitu; a). Sikap terbuka, ini berkenaan dengan pelayanan klien, karena melayani secara cuma-cuma, b). Sikap wajar, ini berkenan dengan perbuatan yang tidak berlebihan, tidak otoriter, tidak sok kuasa, tidak kasar, tidak menindas, tidak memeras. (Fauzi, 2002: 77)

Kedua, Otentik artinya menghayati dan mewujudkan diri sesuai dengan karakter, kepribadian yang sebenarnya: a). Tidak menyalahgunakan wewenang. b). Tidak melakukan perbuatan yang merendahkan martabat (perbuatan tercela). c). Mendahulukan kepentingan klien. d). Berani berinisiatif dan berbuat sesuatu dengan bijaksana, tidak semata-mata menunggu perintah atasan. e). Tidak mengisolasi diri dari pergaulan sosial.

Ketiga, Bertanggungjawab: a). Kesetiaannya melakukan dengan sebaikbaiknya dalam lingkup profesinya. b). Bertindak secara professional, tanpa membedakan perkara bayaran dan perkara prodeo (cuma-cuma). c). Kesediaan memberikan laporan pertanggungjwaban atas pelaksanaan kewajibannya. (Ropaun, 2001: 33)

Keempat, Kemandirian moral, tidak mudah terpengaruh atau tidak mudah mengikuti pandangan moral yang terjadi di sekitarnya, melainkan membentuk penilaian dan mempunyai pendirian sendiri. Mandiri secara moral berarti tidak dapat dibeli oleh pendapat mayoritas, tidak berpengaruh oleh pertimbangan untung-rugi (pamrih), menyesuaikan diri dengan kesusilaan agama. Keberanian moral adalah keberanian terhadap hati nurani yang menyatakan untuk menanggung resiko komplit, keberanian untuk: a). Menolak segala bentuk suap, pungli, upeti, korupsi, kolusi. b). Menolak tawaran damai. c). Menolak penyelesaian “jalan damai". (Frans, 1995: 25) 


\section{KESIMPULAN}

Peran advokat dalam penegakan hukum ekonomi di Indonesia memang sangat dibutuhkan. Tanpa adanya peran advokat, maka penegakan hukum, khususnya yang berkaitan dengan hukum ekonomi tidak akan dapat ditegakkan. Oleh karenanya dibutuhkan profesionalitas hukum, yang bekerja sesuai dengan kode etik, nilai moralitas dan tanggungjawab. Profesionalisme biasanya dipahami sebagai suatu kualitas, yang wajib dipunyai setiap eksekutif yang baik. Di dalamnya terkandung beberapa ciri, yaitu: punya keterampilan tinggi dalam suatu bidang, serta kemahiran dalam mempergunakan peralatan tertentu yang diperlukan dalam pelaksanakan tugas yang bersangkutan dengan bidang tadi; punya ilmu dan pengalaman serta kecerdasan dalam menganalisa suatu masalah, dan peka di dalam membaca situasi, cepat dan tepat serta cermat dalam mengambil keputusan terbaik atas dasar kepekaan; punya sikap berorientasi ke hari depan, sehingga punya kemampuan mengantisipasi perkembangan lingkungan yang terbentang di hadapannya; punya sikap mandiri berdasarkan keyakinan akan kemampuan pribadi ('izzat al-nafs atau self-confidensce), serta terbuka menyimak dan menghargai pendapat orang lain, namun cermat dalam memilih yang terbaik bagi diri dan perkembangan pribadinya. Selain itu seorang advokat paling tidak harus memiliki empat kriteria nilai moral yang harus mendasari kepribadian profesional hukum dirinya, yaitu; memiliki kejujuran sebagai dasar utama bersikap, sikap otentik artinya menghayati dan mewujudkan diri sesuai dengan karakter dan kepribadian sebenarnya, bertanggungjawab, dan memiliki kemandirian moral.

\section{DAFTAR PUSTAKA}

Abdurrahman, (1986), Tebaran Pikiran Tentang Studi Hukum dan Masyarakat, Jakarta: Media Sarana Press.

Achmad Ali, (2002), Keterpurukan Hukum Di Indonesia, (Penyebab dan Solusinya), Jakarta: Ghalia Indonesia.

Emil Salim (2012), dalam Pembinaan Hukum Ekonomi Nasional, Ceramah pada Pembinaan Hukum Ekonomi Nasional dalam BPHN.

Fauzi Yusuf Hasibuan, (2002), Strategi Penegakan Hukum, Jakarta: Fauzie \& Partners.

Frans Hendra Winata, (1995), Advokat Indonesia, Citra, idealism dan Keprihatinan,Jakarta: Pustaka Sinar Harapan.

Ropaun Rampe, (2001), Teknik Praktek Advokat, Jakarta: Gramedia Widiasarana Indonesia.

Soerjono Soekanto, (1999), Pokok-pokok Sosiologi hukum, Jakarta: Raja Grafindo Persada.

Suhrawardi K. Lubis, (1994), Etika Profesi Hukum, Jakarta: Sinar Grafika. 